\title{
Instituto de Estudos Brasileiros da Universidade de São Paulo
}

O Instituto de Estudos Brasileiros da USP (IEB/ USP) foi fundado na década de 1960 por um grupo de professores e intelectuais ligados a esta universidade, sob a liderança de Sérgio Buarque de Holanda. Desde seu início, o Instituto pretendeu ser um centro multidisciplinar e multitemático que congregasse estudos especializados sobre o Brasil nas diversas áreas das Ciências Humanas.

Seu acervo inicia-se em 1962 com a aquisição da Brasiliana do historiador Yan de Almeida Prado, seguido por vários outros fundos pessoais de intelectuais brasileiros, entre eles Mário de Andrade, Guimarães Rosa, Graciliano Ramos, Pierre Monbeig e Anita Malfatti, José Honório Rodrigues, compondo hoje um expressivo e rico conjunto de fontes primárias, muitas raras. Compreendendo documentos de diversas naturezas, os acervos desses estudiosos estão distribuídos entre a Biblioteca, a Coleção de Artes Visuais e o Arquivo da instituição, recebendo os cuidados necessários para a sua restauração, conservação e consulta da parte dos funcionários especializados de cada seção e do Laboratório de Conservaçáo e Restauro.

Com o desenvolvimento de suas pesquisas e o crescimento de sua infra-estrutura, o instituto passou a oferecer disciplinas da graduação específicas para diversas unidades da USP e cursos de extensão universitária para o público interessado. Dentre eles, merece destaque o Curso de Organizaçáo de Arquivos, ministrado há cerca de 20 anos pela instituição e que tem formado profissionais que hoje se encontram em diversas partes do país e do mundo.

No segundo semestre de 2009, iniciaramse as atividades regulares do Programa de Pósgraduação Culturas e Identidades Brasileiras do IEB, que tem como orientadores os professores do Instituto. Em sua primeira turma, o programa começa seus trabalhos com o oferecimento de três disciplinas que abordam os estudos brasileiros a partir de diferentes enfoques, contribuindo para uma visão interdisciplinar: Análise e interpretação do Brasil; A criação de Macunaíma na biblioteca de Mário de Andrade: matrizes e marginália em uma perspectiva genética; Articulaçôes entre as artes, no Brasil, do século XIX à primeira metade do XX. Entre 2008 e 2009 a ampliação do quadro docente possibilitou o fortalecimento das áreas de História Econômica, Literatura Brasileira, Música (Etnomusicologia) e Geografia assim como a criação no IEB/USP de novas áreas de docência e pesquisa em Sociologia e Antropologia.

O IEB preocupa-se também em difundir o produto dessas pesquisas através de publicações e eventos culturais. Nas últimas décadas, o Instituto contribuiu para a publicação de obras ligadas aos seus estudos e acervos, além de manter, atualmente, a revista eletrônica Almanack Braziliense e a Revista do IEB. Na própria instituição, são mantidas exposições gratuitas: uma permanente ( $A$ arte brasileira pelo olhar 
342 Instituto de Estudos Brasileiros da Universidade de São Paulo

de Mário de Andrade) e outras temporárias. A atual é Paisagens colecionadas: acervo Mário de Andrade, cuja abertura foi acompanhada do ciclo de conferências Paisagens, cidades, nature$z a$, que contemplou as relaçóes entre paisagem, cidade e natureza através da interlocução sobre fenômenos, objetos ou narrativas do século 15 ao século 20 na Europa e na América.

Para facilitar o acesso ao acervo do instituto, há alguns anos foi implementado um projeto pioneiro de digitalização, que já conta com aproximadamente 100.000 imagens processadas a partir de livros, microfilmes e documentos de vários tipos, entre eles o acervo fotográfico de Mário de Andrade e a Coleção de Cartôes-Postais de Aracy Guimarães Rosa. Há também o atendimento direto aos pesquisadores, digitalizando documentos e obras por eles solicitados, disponibilizados na forma de CD-rom e a constituição de um banco de dados eletrônico através do Projeto Brasil-Ciência em parceria com a FAPESP.

Mais informaçóes sobre o IEB podem ser obtidas em www.ieb.usp.br. 